\title{
Solar Cell Calibration and Measurement Techniques
}

Sheila Bailey, Dave Brinker, and Henry Curtis

Lewis Research Center

Cleveland, Ohio

Phillip Jenkins

Essential Research, Inc.

Cleveland, Ohio

Dave Scheiman

NYMA, Inc.

Brook Park, Ohio

Prepared for the

32nd Intersociety Energy Conversion Engineering Conference cosponsored by AIChE, ANS, SAE, AIAA, ASME, and IEEE

Honolulu, Hawaii, July 27-August 1, 1997

National Aeronautics and

Space Administration

Lewis Research Center 
Available from

NASA Center for Aerospace Information 800 Elkridge Landing Road

Linthicum Heights, MD 21090-2934

Price Code: A02
National Technical Information Service 5287 Port Royal Road Springfield, VA 22100 Price Code: $\mathrm{A} 02$ 


\title{
SOLAR CELL CALIBRATION AND MEASUREMENT TECHNIQUES
}

\author{
Sheila Bailey, Dave Brinker, Henry Curtis \\ NASA Lewis Research Center \\ MS 302-1 \\ Cleveland, Ohio 44135 \\ Phone: 216-433-2228; Fax: 216-433-6106 \\ Phillip Jenkins \\ Essential Research, Inc. \\ NASA Lewis Research Center \\ MS 302-1 \\ Cleveland, Ohio 44135 \\ Phone: 216-433-2233; Fax: 216-433-6106 \\ Dave Scheiman \\ NYMA \\ NASA Lewis Research Center \\ MS 302-1 \\ Cleveland, Ohio 44135 \\ Phone: 216-433-6756; Fax: 216-433-6106
}

\begin{abstract}
The increasing complexity of space solar cells and the increasing international markets for both cells and arrays has resulted in workshops jointly sponsored by NASDA, ESA and NASA. These workshops are designed to obtain international agreement on standardized values for the AMO spectrum and constant, recommend laboratory measurement practices and establish a set of protocols for international comparison of laboratory measurements. A working draft of an ISO standard, WD15387, "Requirements for Measurement and Calibration Procedures for Space Solar Cells" was discussed with a focus on the scope of the document, a definition of primary standard cell, and required error analysis for all measurement techniques. Working groups addressed the issues of Air Mass Zero (AM0) solar constant and spectrum, laboratory measurement techniques, and the international round robin methodology. A summary is presented of the current state of each area and the formulation of the ISO document.
\end{abstract}

\section{INTAODUCTION}

The expanding choice of space solar cells from worldwide vendors has focused attention on the need for an internationally recognized standard value of the Air Mass Zero (AMO) solar constant and spectral intensity distribution and the primary set of standards and protocols to establish equitable comparisons of laboratory measurements around the world. To achieve this universality of calibration and laboratory measurements NASA Lewis Research Center's Photovoltaic Branch initiated a series of workshops jointly sponsored by the National Aeronautics and Space Administration (NASA), the European Space Agency (ESA), and the National Space Development Agency of Japan (NASDA). The First International Workshop on Space Solar Cell Calibration and Measurement Techniques took place in Honolulu, Hawaii in December of 1994 and was attended by thirty-four participants from Japan, the United States and Europe representing not only the space agencies but industry as well (Brinker et al, 1995). The Second Workshop took place in Madrid, Spain in September of 1995 with twenty-five participants, expanding to include China. The Third Workshop occurred at Tsukuba, Japan in November of 1996 with thirty-five participants. There were three established working groups: A. AM0 Solar Constant and Spectrum; B. Laboratory Measurements Techniques; C. International round Robin Methodology. The current draft of the International Organization for Standardization (ISO) standard, WD 15387 was presented by Mr. Kiyota of SHARP Corporation. Dr. Cuquel of CNES presented the CNES balloon flight calibration system and Mr. Scheiman of NASA Lewis Research Center (LeRC) presented the JPL balloon flight calibration method and the LeRC aircraft calibration method. Dr. Bucher of the Fraunhofer Institute discussed the Institute fur Solare Energiesysteme (ISE) Photovoltaic (PV) Charts.

\section{ISO 15387}

Terrestrial solar cell standards are governed by the International Electrotechnical Commission (IEC), specifically the technical committee number 82: Solar Photovoltaic Energy System. However, it was decided that space solar cell standards would fall under the auspices of ISO technical committee number 20: Aircraft and Space Vehicle, sub committee number 14: Space Systems and Operation. Japan proposed ISO standardization of space solar cell calibration at a meeting in 1994 and submitted the first working draft in 1996 with input from the International Workshop participants and other interested parties. The ISO and IEC standards can be compared in the topics which are addressed by each set of standards: requirements for reference solar cells (IEC 904-2), measurement principles for space solar cells with reference to the extraterrestrial solar spectral irradiance data (IEC 903-3), computation of spectral mismatch error introduced in the testing of the solar cells (IEC 904-7), guidance for the spectral measurement of a solar cell (IEC 904-8), solar simulator performance requirements (IEC 904-9), calibration methods 
for primary reference solar cell (IEC 82-101), methods of spectral distribution measurement for the light source (ASTM and JIS standards), measurement of current-voltage (I-V) characteristics (IEC 904-1), procedures for temperature and irradiance corrections to measured I-V characteristics of crystalline silicon solar cells (IEC 891). The scope of the ISO document is restricted to single-junction crystalline space solar cells. The AM0 standard solar cell would record the type of calibration spectrum (extraterrestrial: JPL highaltitude balloon $(36.6 \mathrm{~km})$, CNES high-altitude balloon $(36.6$ $\mathrm{km})$, space shuttle or space station $(500 \mathrm{~km})$; direct sunlight: NASA Lewis high-altitude aircraft $(15.4 \mathrm{~km})$; ground level sunlight: global sunlight, direct normal sunlight; synthetic sunlight: solar simulator or differential spectral response (if applicable). The calibration results will be repeatable within a standard deviation of $\pm 1 \%$. The solar constant, which is slightly variable, is accepted to be $1367 \mathrm{Wm}^{-2} \pm 7 \mathrm{Wm}^{-2}$. The standard temperature test condition is $25 \pm 1{ }^{\circ} \mathrm{C}$. The following data are recorded: identification number, type solar spectrum, cell manufacturer, material type, type of cell package, calibration organization, site and date of calibration, method of calibration, radiometer or standard lamp characteristics (where applicable), AM0 standard solar cell identification (for simulator calibration, where applicable), simulator characteristics, type of temperature sensor, relative spectral response, temperature coefficient of short-circuit current, calibration value $\left(\mathrm{AW}^{-1} \mathrm{~m}^{2}\right)$, and claimed accuracy (with a description of error analysis). The final version of the working draft ISO 15387 will be discussed at the 4th International Workshop in October of 1997 at NASA Lewis Research Center.

\section{WORKING GROUP: AMO SOLAR CONSTANT \& SPECTRUM}

The values identified above were accepted for cell temperature, spectrum, and solar constant corresponding to the most recent cavity measurement in space. It was agreed to solicit "a letter of agreement" from all space calibration agencies in order to reach common reporting conditions; to collect reports of the calibration procedures and a detailed error analysis of all procedures. The following institutions agreed to use the standard measurement conditions (pending completion of current contracts specifying $28^{\circ} \mathrm{C}$ rather than $25^{\circ} \mathrm{C}$ ): NASA, JPL, NASDA, ESA, CNES, CAST, DRA, NREL, Japanese Space Solar Cell Calibration Committee, INTA-Spasolab, HIREC, WYMA, Space System Loral, Essential Research, Hughes, TecStar.

\section{WORKING GROUP: LABORATORY MEASUREMENTS TECHNIQUES}

Single light source simulators, commonly used in laboratories and by commercial vendors, are accurate for single junction gallium arsenide (GaAs) and silicon (Si) solar cells within an experimental error of approximately $1 \%$. The spikes of the Xenon light source of the X25 Spectrolab Single Source Simulator, for example, (see Fig. 1) can become a significant source of error for multi-junction cells unless carefully filtered. Recently, a filtered dual source simulator has become available (see Fig. 2) which provides a closer matched AMO spectrum. The spectral response of a $\mathrm{GaAs} / \mathrm{Ge}$ single junction cell can be seen in Fig. 3 and a GalnP/GaAs/Ge dual junction cell can be seen in Fig. 4 . It should be noted that both spectrally tunable solar simulators and subcell standards for multi-junction cells will be required to obtain $\pm 1 \%$ accuracy. A dual beam pulse solar simulator for module and array testing would be difficult to develop, the more probable option would be a suitably filtered design. A color filter bias light method has been used and verified with three junction devices (Bucher et al, 1995). A proposal has been submitted to NASA from the Photovoltaic and Space Environments Branch at NASA Lewis and the Ohio Aerospace Institute to utilize the international space station as a solar cell calibration and measurement facility.

\section{WORKING GROUP: INTERNATIONAL ROUND ROBIN METHODOLOGY}

The first international round robin of solar cell calibration was established following the 1st International Workshop. There were 12 samples (4 each from NASA, ESA, and NASDA) which would be measured by NASA, ESA, NASDA and the Chinese Academy of Space Technology (CAST) and then reflown at NASA. These samples were silicon cells, GaAs cells, and high efficiency silicon cells. The first round robin is complete. These cells will now be cycled through other organizations, e.g. DRA, JPL, NREL, ISE, etc. Measurement data will be reported at the 26th IEEE-PVSC in October of 1997.

A second round robin of $\mathrm{Si}$ and GaAs solar cells was proposed with NASA, JPL, and CNES providing the cells, 2 cells each; $1 \mathrm{Si}$ and $1 \mathrm{GaAs}$. They would be measured at NASA Lewis then sent to CNES and JPL. These extraterrestrial measurements are anticipated to be available for publication at the 2nd World Conference on Photovoltaic Energy Conversion in July of 1998. After the extraterrestrial measurements the cells would be measured by NASA and DRA in a solar simulator, CAST by direct sunlight, and ESASpasolab by global sunlight with ISE to be determined. It was agreed to begin a round robin of $\mathrm{GaInP} / \mathrm{GaAs} / \mathrm{Ge}$ dual junction cells, not to compare results, but to assess measurement techniques for multi-junction cells.

\section{CONCLUSION}

The three International Workshops held since 1994 have involved eight countries, government organizations and corporations. They have provided a forum for discussion regarding the ISO 15387 standards, achieved agreement on the standardized values of the AMO solar constant and spectral intensity distribution, established a set of protocols for making interlaboratory comparison measurements, initiated round robin cell calibration series, and addressed the complicated issue of multi-junction solar cell measurements. The 4th International Workshop on Space Solar Cells will be held at NASA Lewis Research Center, October 6th - 9th, 1997. For further information contact Dave Brinker (Phone: 216-4332236, Fax: 216-433-6106, dbrinker@lerc.nasa.gov.

\section{REFERENCES}

Brinker, D.J., Curtis, H.B., Flood, DJ., Jenkins, P., Scheiman, D.A., "A Summary of the International Workshops on Space Solar Cell Calibration and Measurement Techniques", Space Photovoltaic Research and Technology Proceedings, 186-190, (1995).

Bucher, $\mathbf{K}$ and Kunzelmann, "The FhG-ISE PV Charts: Assessment of PV Device Performance", 13th European Photovoltaic Solar Energy Conference Proceedings, 23522357, (1995). 


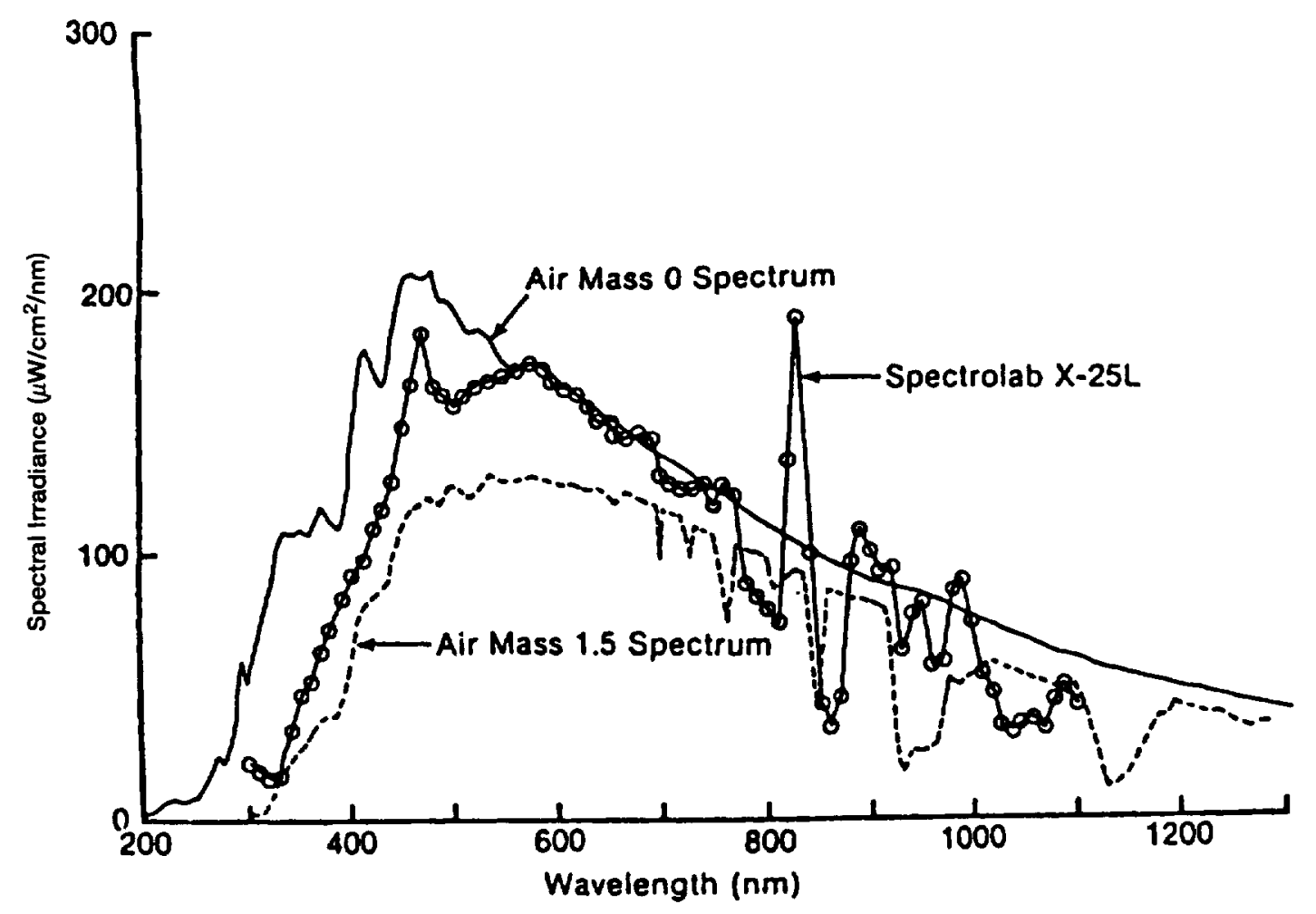

FIG. 1 AIR MASS 0 AND 1.5 SPECTRUM AND SPECTROLAB X-25L SPECTRUM

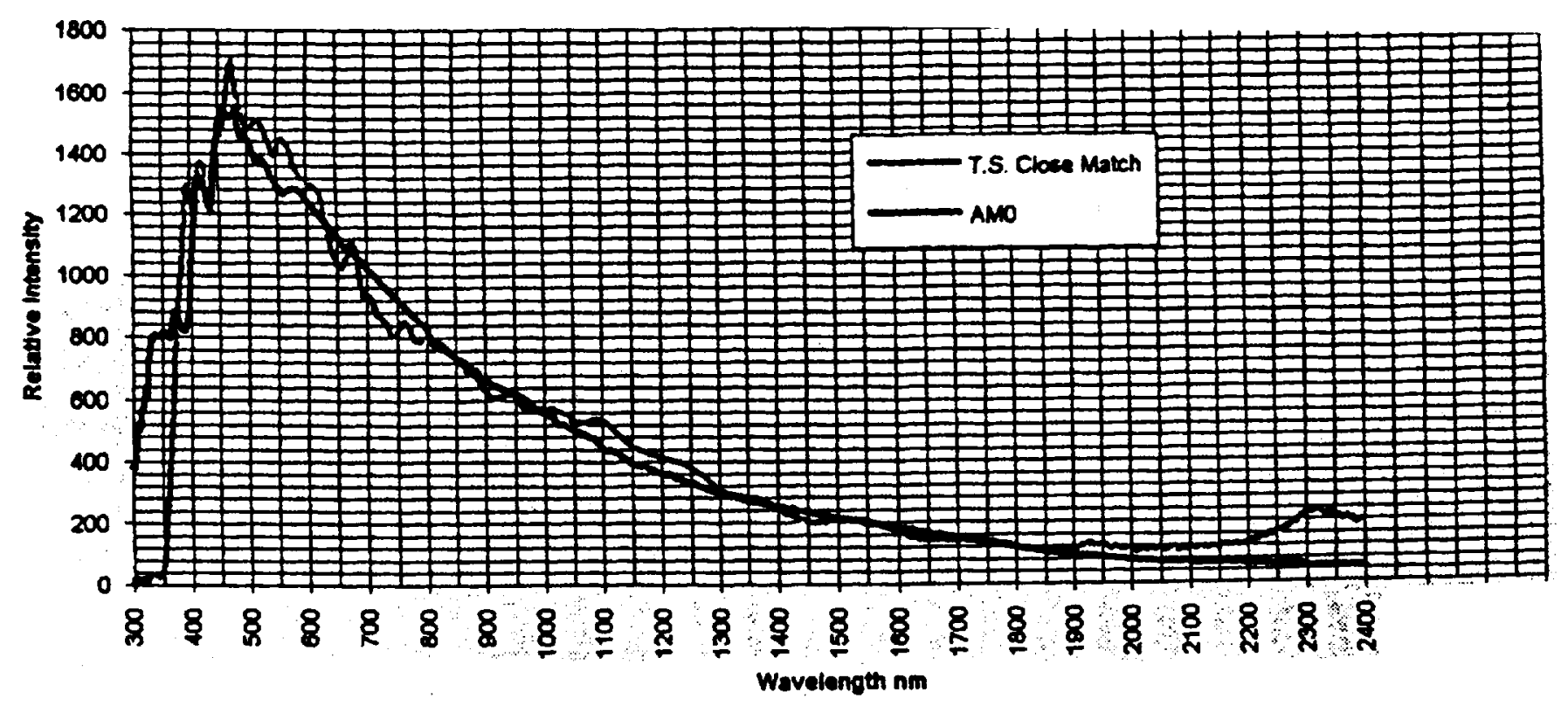

FIG. 2 TS SPACE SYSTEMS MULTIPLE SOURCE SIMULATOR 


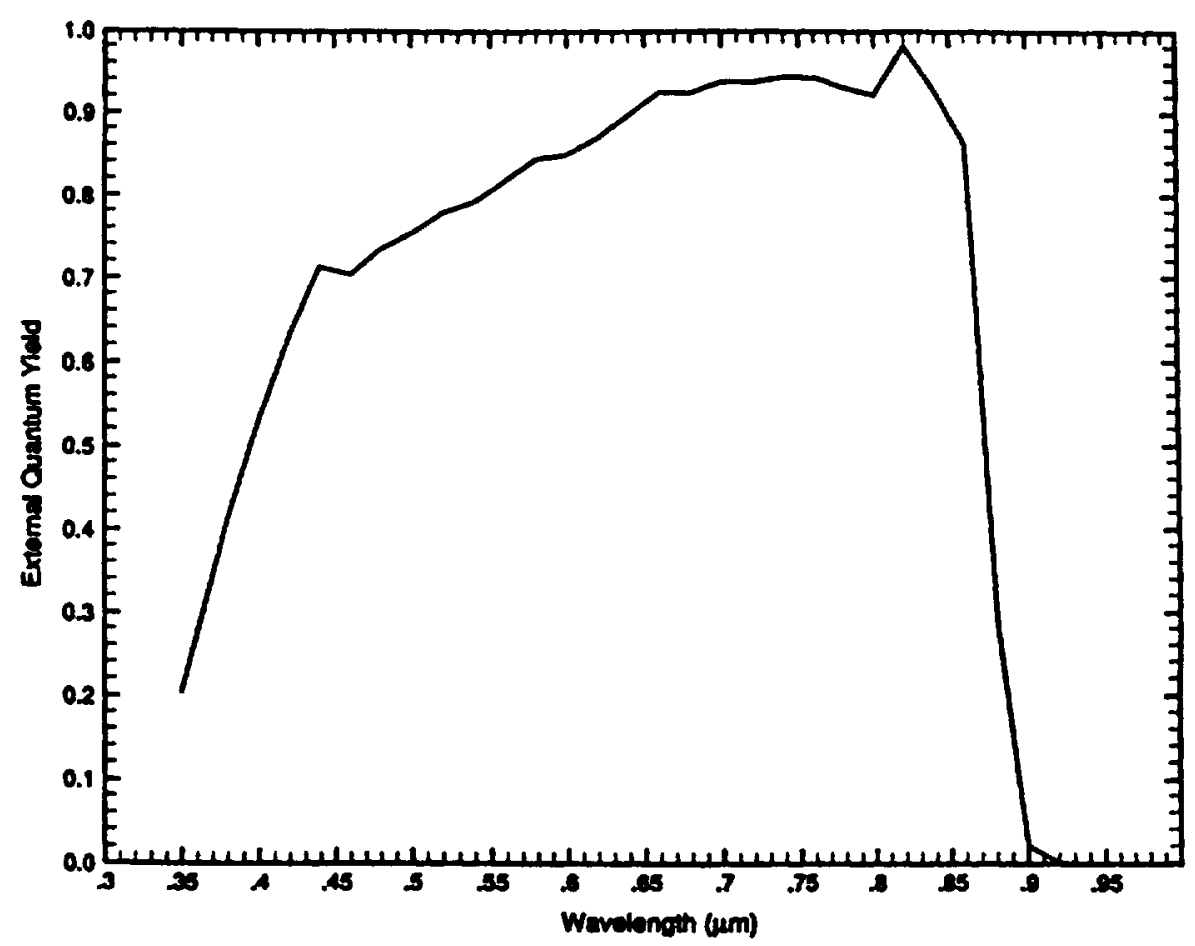

FIG. 3 SPECTRAL RESPONSE OF A GaAs/Ge SOLAR CELL

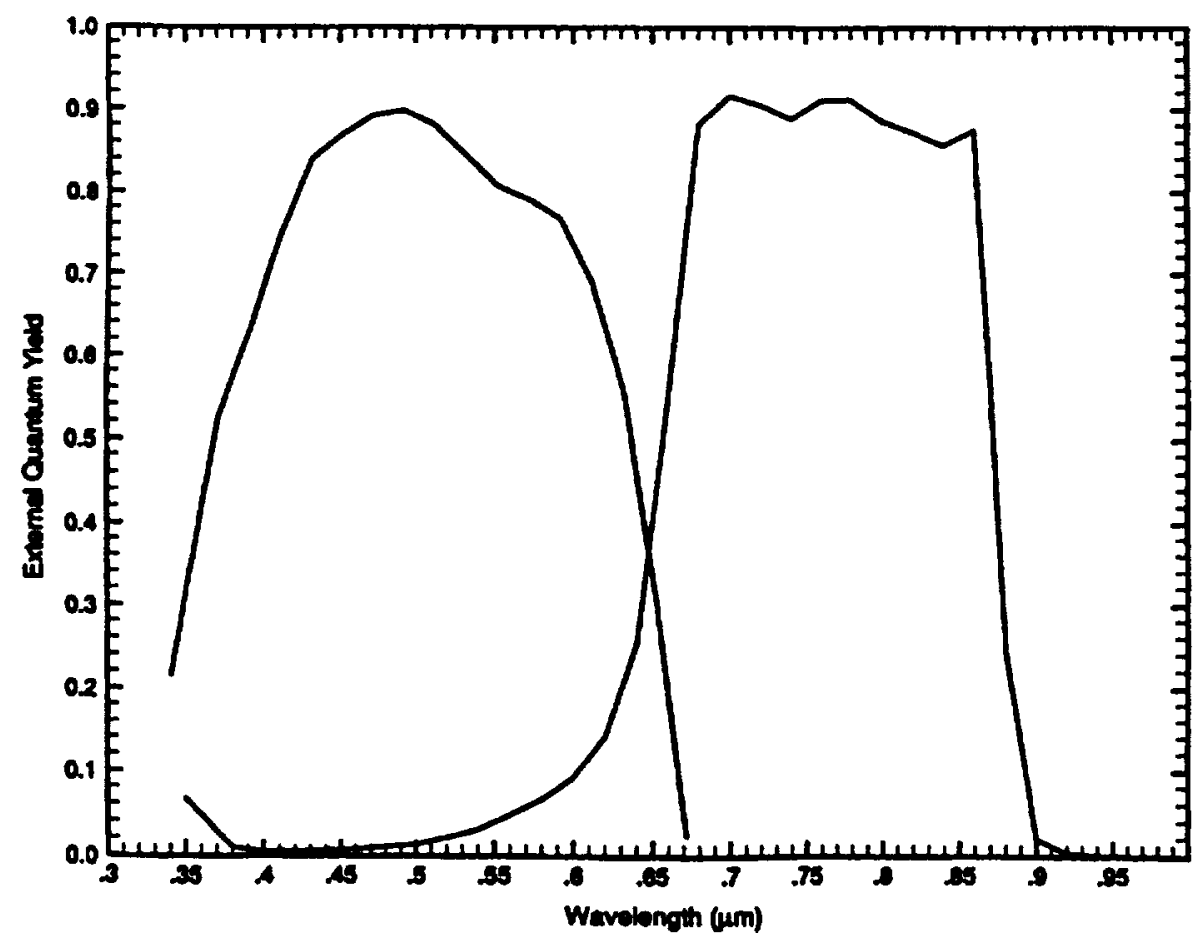

FIG. 4 SPECTRAL RESPONSE OF A GaIn/GaAs/Ge SOLAR CELL 
Public reporting burden for this collection of information is estimated to average 1 hour per response, including the time for reviewing instructions, searching existing data sources, gathering and maintaining the data needed, and completing and reviewing the collection of information. Send comments regarding this burden estimate or any other aspect of this collection of information, including suggestions for reducing this burden, to Washington Headquarters Services, Directorate for information Operations and Reports, 1215 Jefferson Davis Highway, Suite 1204, Artington, VA 22202-4302, and to the Office of Management and Budget, Paperwork Reduction Project (0704-0188), Washington, DC 20503.

\begin{tabular}{|l|l|l}
\hline 1. AGENCY USE ONLY (Leave blank) & $\begin{array}{c}\text { 2. REPORT DATE } \\
\text { November } 1997\end{array}$ & $\begin{array}{r}\text { 3. REPOAT TYPE AND DATES COVERED } \\
\text { Technical Memorandum }\end{array}$
\end{tabular}

4. TITLE AND SUBTTLEE 5. FUNDING NUMBERS

Solar Cell Calibration and Measurement Techniques

6. AUTHOR(5)

WU-632-1A-1A

Sheila Bailey, Dave Brinker, Henry Curtis, Phillip Jenkins, and Dave Scheiman

7. PERFOAMING ORGANIZATION NAME(S) AND ADDAESS(ES)

National,Aeronautics and Space Administration

Lewis Research Center

Cleveland, Ohio 44135-3191

8. PERFORMING ORGANIZATION REPORT NUMBER

E-10905

9. SPONSORINGMONITORING AGENCY NAME(S) AND ADDRESS(ES)

National Aeronautics and Space Administration

Washington, DC 20546-0001

10. SPONSORING/MONITORING AGENCY REPORT NUMBER

NASA TM-113155

IECEC-97534

11. SUPPLEMENTARY NOTES

Prepared for the 32nd Intersociety Energy Conversion Engineering Conference cosponsored by AIChE, ANS, SAE, AIAA, ASME, and IEEE, Honolulu, Hawaii, July 27-August 1, 1997. Sheila Bailey, Dave Brinker, and Henry Curtis, NASA Lewis Research Center; Phillip Jenkins, Essential Research, Inc., Cleveland, Ohio 44135 (work funded by NASA Contract NAS327243); Dave Scheiman, NYMA, Inc., 2001 Aerospace Parkway, Brook Park, Ohio 44142 (work funded by NASA Contract NAS3-27186). Responsible person, Sheila Bailey, organization code 5410, (216) 433-2228.

\begin{tabular}{|l|l} 
12a. DISTRIBUTIONAVAILABILTYY STATEMENT & 12b. DISTRIBUTION CODE
\end{tabular}

Unclassified - Unlimited

Subject Categories: 33 and $20 \quad$ Distribution: Nonstandard

This publication is available from the NASA Center for AeroSpace Information, (301) 621-0390.

13. ABSTRACT (Maximum 200 words)

The increasing complexity of space solar cells and the increasing international markets for both cells and arrays has resulted in workshops jointly sponsored by NASDA, ESA and NASA. These workshops are designed to obtain international agreement on standardized values for the AMO spectrum and constant, recommend laboratory measurement practices and establish a set of protocols for international comparison of laboratory measurements. A working draft of an ISO standard, WD15387, "Requirements for Measurement and Calibration Procedures for Space Solar Cells" was discussed with a focus on the scope of the document, a definition of primary standard cell, and required error analysis for all measurement techniques. Working groups addressed the issues of Air Mass Zero (AM0) solar constant and spectrum, laboratory measurement techniques, and the international round robin methodology. A summary is presented of the current state of each area and the formulation of the ISO document.

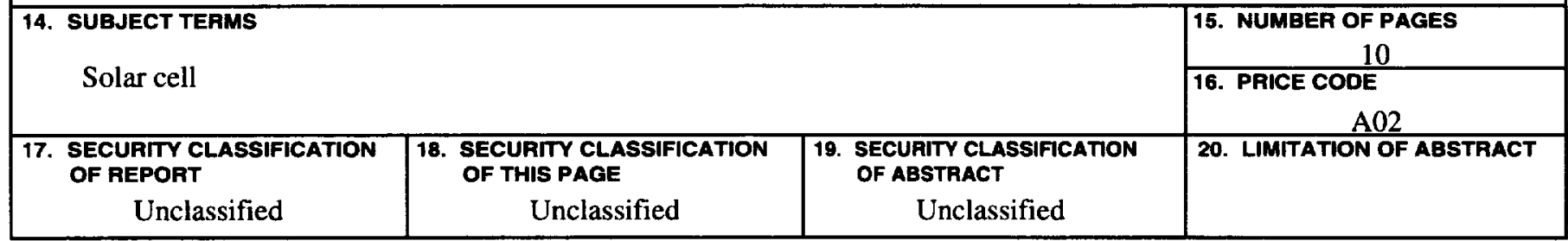

NSN 7540-01-280-5500 